\title{
Analysis of Factors Affecting Poor Nutrition in Infants Aged 0-6 Months
}

\author{
Maryam Latifah Harahap ${ }^{1}$, Elvi Suryani ${ }^{2}$, Nur Aliyah Rangkuti ${ }^{3}$, Novita Sari Batubara ${ }^{4}$, Rya Anastasya \\ Siregar $^{5}$, Ratna Dewi Siregar ${ }^{6}$ \\ ${ }^{1,2}$ Diploma 3 Study Program, Darmais Padangsidimpuan Midwifery Academy, Indonesia \\ ${ }_{3,4,5,6}$ Health faculty, Aufa Royhan University, Indonesia
}

\begin{abstract}
Article Info
Article history:

Received November 23, 2021

Revised December 11, 2021

Accepted January 07, 2022

\section{Corresponding Author:}

Maryam Latifah Harahap

Diploma 3 Study Program,

Darmais Padangsidimpuan

Midwifery Academy, Indonesia

Email:

maryamlatifahharahap@gmail.

com

ABSTRACT

Malnutrition (kwashiorkor) is a form of malnutrition. Malnutrition itself can be understood as a nutritional error. It can be in the form of deficiency or excess of nutrients. This research is a case control study. The population in this study were 45 people. Data was collected through medical records and interviews using a questionnaire. Data were analyzed univariately, bivariately using Chi-Square test at $95 \%$ confidence level $(\mathrm{P}<0.05)$ and multivariate using multiple logistic regression test. The results showed that the results of the statistical test of the knowledge independent variable obtained a Sig value of $0.001<\mathrm{p}: 0.05$, family income obtained a Sig value of $0.001<\mathrm{p}: 0.05$, exclusive breastfeeding obtained a Sig value of $0.001<$ $\mathrm{p}: 0.05$, which means that there is a significant relationship between the independent and dependent variables. The most dominant variable that has the greatest influence on the incidence of malnutrition is knowledge which has the largest Exp (B) value of 112,687 with a regression coefficient (B) of 4.725. The Health Office of South Tapanuli Regency is expected to be able to increase outreach and counseling programs about the importance of nutritional status in infants aged 0-6 months.
\end{abstract}

Keywords:

Infants, malnutrition, factors that influence malnutrition

This article is licensed under a Creative Commons AttributionShareAlike 4.0 International License.

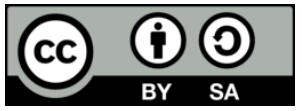

\section{INTRODUCTION}

Malnutrition, also known as kwashiorkor in the medical world, is a form of malnutrition. Malnutrition itself can be understood as an error in nutrition. Errors can be in the form of deficiency or excess of nutrients, which basically kwashiorkor can be interpreted as a condition where a person lacks intake that contains energy and protein. Data on child mortality according to the World Health Organization (WHO, 2021) found that the causes of death were complications of premature birth, pneumonia, birth asphyxia, diarrhea and malaria. It is estimated that about $45 \%$ of all child deaths are related to malnutrition, which makes children more susceptible to disease . Among 33 provinces in Indonesia, 18 provinces have a prevalence of malnutrition above the national prevalence rate, which ranges from $21.2 \%$ to $33.1 \%$ [16].

In Southeast Asia, the prevalence of underweight was the highest at $39 \%$ and the lowest in Latin America was $8 \%$. The prevalence of wasting is around 35\% in both Africa and Southeast Asia, and stunting is between $20 \%$ and $30 \%$ in all regions except Latin America. In Indonesia, stunting is a serious problem and is also a major nutritional problem being faced (Situation of Short Toddlers (Stunting) in Indonesia, 2018). If this problem is chronic, it will affect cognitive function, namely a low level of intelligence and have an impact on the quality of human resources. The problem of stunting has a fairly serious impact; Among other things, the short term is associated with infant/toddler morbidity and mortality, the medium term is associated with low intellectual and cognitive abilities, and the long term is associated with the quality of human resources and the problem of degenerative diseases in adulthood [8]-[9]

North Sumatra, the prevalence of malnutrition and under-five children in 2017 was $18.2 \%$, consisting of $5.2 \%$ of malnutrition and $13 \%$ of undernourished. When viewed by district/city, the highest prevalence of malnutrition and malnutrition was found in West Nias Regency at 36.8\%, Nias Regency at 33.9\%, North Nias 
Regency at $28.4 \%$, and the prevalence of malnutrition and undernutrition. the lowest was Medan at $6 \%$, Pakpak Bharat Regency at $11.7 \%$, Deli Serdang Regency at $12.5 \%$, and South Tapanuli at $18.36 \%$ [15]. According to research by Eka Prasetia Hati Baculu, M.Juffrie, Siti Helmyati, regarding the Risk Factors of Malnutrition in Toddlers in Donggala Regency, Central Sulawesi Province, it shows that there is a significant relationship between energy intake levels and a history of infectious diseases with the incidence of malnutrition $(\mathrm{p}<0.05)$, while the level of protein intake and parenting did not show a significant relationship with the incidence of malnutrition (Eka, 2015). According to Naibaho and Gultom's research, there is a relationship between the effect of providing health promotion on knowledge $(\mathrm{p}=0.000)$ and attitudes $(\mathrm{p}=0.000)$ and the average value of knowledge before the intervention is 28.86 while after the intervention is 34.75 as well as the attitude variable before the intervention. intervention 26.84 and after intervention 38.84. (Clara, 2016).

Another study conducted by Mazarina Devi on the Analysis of Factors Affecting the Nutritional Status of Toddlers in Rural Areas showed that the multivariate test results showed that the most dominant factors related to nutritional status were the type of work of the father and the type of work of the mother. (Mazarina, 2010). The results of the initial survey conducted by researchers through direct interviews with ten mothers who have babies, stated that they still do not understand how to cope so that babies do not experience malnutrition. Seven of those who had babies stated that during infancy their children did not get exclusive breastfeeding at all due to the provision of formula milk and by reason of the belief in giving sugar after the baby was born and giving food such as bananas, rice to meet the baby's needs because by giving these foods the baby will grow up quickly and be full quickly, three of them stated that the food provided was in the form of food that was not diverse, such as rice with tofu or tempeh and even eggs or with vegetables and instant noodles on the grounds that they were unable to provide varied food because of the economic constraints of the average family. husband works as a laborer. The purpose of the study was to analyze the factors that influence malnutrition in infants aged 0-6 months at the Vegetable Matinggi Subdistrict Health Center, South Tapanuli in 2021.

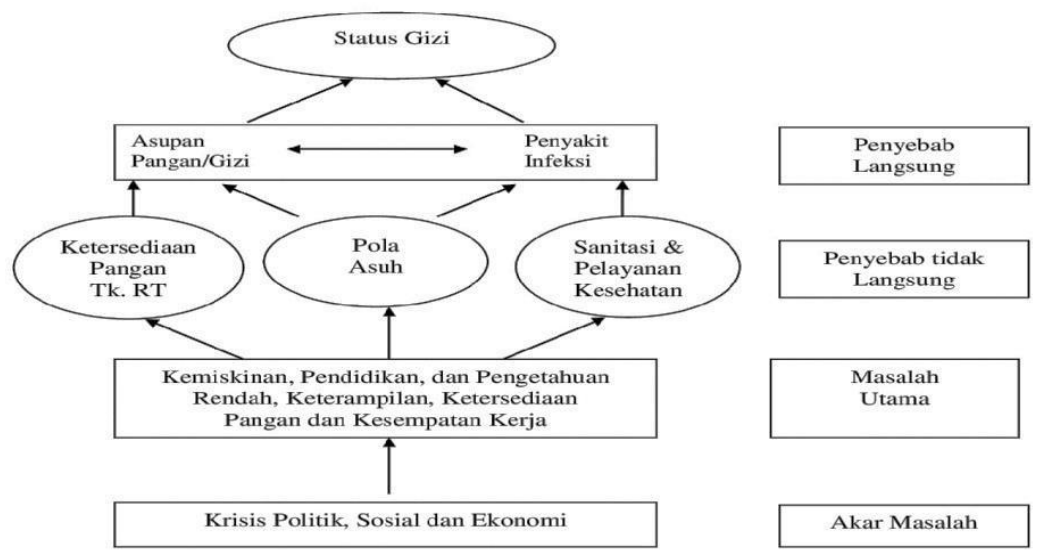

Figure 1. Theoretical Foundation

\section{METHOD}

The type of research used is analytic research, this research design uses a case control research design (Sugiyono, 2008). This research was conducted in the Work Area of the Matinggi Vegetable Health Center. The study is planned for December 2021 to January 2021. The case population in this study were all mothers who had babies aged 0-6 months who suffered from malnutrition. The control population is mothers who have babies aged 06 months who do not suffer from malnutrition with the same number of cases as 45 people. so the total population in this study was 90 people. The number of case samples in this study was 45 people and the number of controls was 45 people, namely $1: 1$, so the number of samples in this study was 90 people, the data used were primary and secondary data. The data were analyzed and tested by multiple logistic regression.

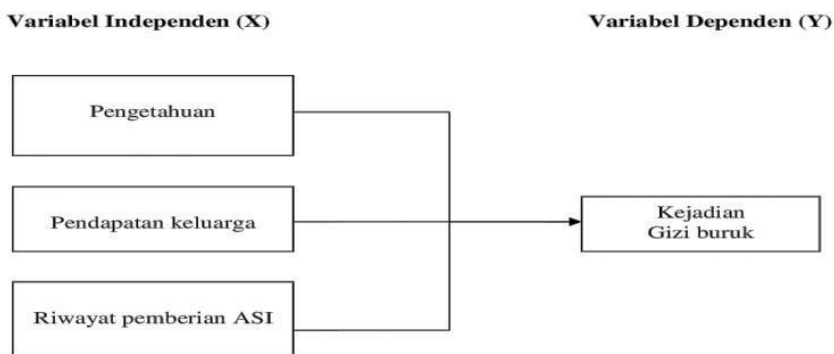

Figure 2. Research Concept Framework 


\section{RESULTS AND DISCUSSION}

\subsection{Results}

Table 1. Distribution Based on Characteristics of Respondents at Sayurmatinggi Health Center in 2021

\begin{tabular}{|c|c|c|c|c|c|}
\hline \multirow{2}{*}{ No. } & \multirow{2}{*}{$\begin{array}{c}\text { Characteristics of } \\
\text { Respondents }\end{array}$} & \multicolumn{2}{|c|}{ Case } & \multicolumn{2}{|c|}{ Control } \\
\hline & & $\mathbf{n}$ & $\%$ & $\mathbf{n}$ & $\%$ \\
\hline \multirow[t]{4}{*}{1.} & Age & & & & \\
\hline & 19-30 Year & 11 & 24,4 & 11 & 24,4 \\
\hline & 31-42 Year & 34 & 75,6 & 34 & 75,6 \\
\hline & Total & 45 & 100,0 & 45 & 100,0 \\
\hline \multirow[t]{3}{*}{2.} & Gender & & & & \\
\hline & Female & 45 & 100,0 & 45 & 100,0 \\
\hline & Total & 45 & 100,0 & 45 & 100,0 \\
\hline \multirow[t]{3}{*}{3.} & Ethnic group & & & & \\
\hline & Mandailing Batak & 45 & 100,0 & 45 & 100,0 \\
\hline & Total & 45 & 100,0 & 45 & 100,0 \\
\hline \multirow[t]{6}{*}{4.} & Education & & & & \\
\hline & Primary School & 7 & 15,5 & 8 & 17,7 \\
\hline & Junior high school & 22 & 48,8 & 21 & 46,6 \\
\hline & Senior High School & 15 & 33.3 & 14 & 31,1 \\
\hline & College & 1 & 2,22 & 2 & 4,44 \\
\hline & Total & 45 & 100.0 & 45 & 100,0 \\
\hline \multirow[t]{6}{*}{5.} & Job & & & & \\
\hline & $\begin{array}{l}\text { Government } \\
\text { Employees }\end{array}$ & 0 & & 0 & 0 \\
\hline & Entrepreneur & 1 & 2,22 & 3 & 6,66 \\
\hline & Farmer & 3 & 6,66 & 5 & 11,1 \\
\hline & Housewife & 41 & 91,1 & 37 & 82,2 \\
\hline & Total & 45 & 100,0 & 45 & 100,0 \\
\hline \multirow[t]{3}{*}{6.} & $\begin{array}{l}\text { Malnutrition } \\
\text { Diagnosis }\end{array}$ & & & & \\
\hline & $\begin{array}{l}\text { Have you ever had a } \\
\text { child diagnosed with } \\
\text { malnutrition? }\end{array}$ & 45 & 100,0 & 45 & 100,0 \\
\hline & Total & 45 & 100,0 & 45 & 100,0 \\
\hline
\end{tabular}

Table 2. Frequency Distribution of Respondents Based on Knowledge Category at Sayurmatinggi Health Center in 2021

\begin{tabular}{|c|c|c|c|c|c|c|c|}
\hline \multirow{3}{*}{ No. } & \multirow{3}{*}{ Knowledge } & \multicolumn{4}{|c|}{ Respondent Status } & \multicolumn{2}{|c|}{ Amount } \\
\hline & & \multicolumn{2}{|c|}{ Case } & \multicolumn{2}{|c|}{ Control } & \multirow{2}{*}{$\mathbf{f}$} & \multirow{2}{*}{$\%$} \\
\hline & & $\mathbf{F}$ & $\%$ & $\mathbf{F}$ & $\%$ & & \\
\hline 1. & Good & 17 & 37,8 & 34 & 75,6 & 51 & 57 \\
\hline 2. & Not good & 28 & 62,2 & 11 & 24,4 & 39 & 43 \\
\hline \multicolumn{2}{|c|}{ Total } & 45 & 100,0 & 45 & 100,0 & 90 & 100,0 \\
\hline
\end{tabular}

Table 3. Frequency Distribution of Respondents by Category of Family Income at Sayurmatinggi Health Center in 2021

\begin{tabular}{ccccccccc}
\hline \multirow{2}{*}{ No. } & \multirow{3}{*}{ Family Income } & \multicolumn{3}{c}{ Respondent Status } & \multicolumn{3}{c}{ Amount } \\
\cline { 3 - 8 } & & & \multicolumn{3}{c}{ Case } & Control & f & \% \\
\cline { 3 - 8 } & & fow & & \% & f & \% & \\
\hline 1. & & 25 & 55,6 & 3 & 6,7 & 28 & 31 \\
2. & High & & 20 & 44,4 & 42 & 93,3 & 62 & 69 \\
\hline & & Total & $\mathbf{4 5}$ & $\mathbf{1 0 0 , 0}$ & $\mathbf{4 5}$ & $\mathbf{1 0 0 , 0}$ & $\mathbf{9 0}$ & $\mathbf{1 0 0 , 0}$ \\
\hline
\end{tabular}


Table 4. Frequency Distribution of Respondents by Category of Exclusive Breastfeeding at the Sayur Matinggi Health Center in 2021

\begin{tabular}{|c|c|c|c|c|c|c|c|}
\hline \multirow{3}{*}{ No. } & \multirow{3}{*}{ Exclusive Breastfeeding } & \multicolumn{4}{|c|}{ Respondent Status } & \multicolumn{2}{|c|}{ Amount } \\
\hline & & \multicolumn{2}{|c|}{ Case } & \multicolumn{2}{|c|}{ Control } & \multirow{2}{*}{$\mathbf{f}$} & \multirow{2}{*}{$\%$} \\
\hline & & $\mathbf{f}$ & $\%$ & $\mathbf{f}$ & $\%$ & & \\
\hline 1. & Not given & 32 & 71,1 & 3 & 6,7 & 35 & 39 \\
\hline 2. & Given & 13 & 28,9 & 42 & 93,3 & 55 & 61 \\
\hline & Total & 45 & 100,0 & 45 & 100,0 & 90 & 100,0 \\
\hline
\end{tabular}

Table 5. Cross Tabulation of the Relationship between Knowledge and Malnutrition in Infants aged 0-6 Months at Sayurmatinggi Health Center in 2021

\begin{tabular}{|c|c|c|c|c|c|c|c|c|}
\hline \multirow{3}{*}{ Pengetahuan } & \multicolumn{4}{|c|}{ Malnutrition Incident } & \multirow{2}{*}{\multicolumn{2}{|c|}{ Amount }} & \multirow{3}{*}{ p-value } & \multirow{3}{*}{$\begin{array}{c}\text { OR } \\
(95 \% \mathrm{CI})\end{array}$} \\
\hline & \multicolumn{2}{|c|}{ Gizi Buruk } & \multicolumn{2}{|c|}{$\begin{array}{c}\text { Tidak } \\
\text { Gizi Buruk } \\
\end{array}$} & & & & \\
\hline & $\mathbf{F}$ & $\%$ & $\mathbf{F}$ & $\%$ & $\mathbf{F}$ & $\%$ & & \\
\hline Good & 17 & 37,8 & 34 & 75,6 & 51 & 56,7 & & \\
\hline Not Good & 28 & 62,2 & 11 & 24,4 & 39 & 43,3 & 0,001 & $\begin{array}{c}5,091 \\
(2,052-12,628)\end{array}$ \\
\hline Total & 45 & 100,0 & 45 & 100,0 & 90 & 100,0 & & \\
\hline
\end{tabular}

Table 6. Chi-Square Test Results

\begin{tabular}{clcc}
\hline No. & \multicolumn{1}{c}{ Independent Variable } & Significant & Description \\
1. & Knowledge & 0,001 & There's a Relationship \\
2. & Family Income & 0,001 & There's a Relationship \\
3. & Exclusive Breastfeeding & 0,001 & There's a Relationship \\
\hline
\end{tabular}

Table 7. Regression Model Feasibility Test Results

\begin{tabular}{cccc}
\hline Step & Chi-square & df & Sig. \\
\hline 1 & 9.350 & 8 & 0.134 \\
\hline
\end{tabular}

Table 8. Assessing the Overall Regression Model

\begin{tabular}{cccc}
\hline Step & $\begin{array}{c}\mathbf{- 2} \text { Log } \\
\text { likelihood }\end{array}$ & $\begin{array}{c}\text { Cox \& Snell R } \\
\text { Square }\end{array}$ & Nagelkerke R Square \\
\hline 1 & 45.364 & 0.591 & 0.788 \\
\hline
\end{tabular}

Table 9. Results of Multiple Logistic Regression Analysis by Incorporating All Candidate Variables in the Model

\begin{tabular}{|c|c|c|c|c|c|}
\hline \multirow{2}{*}{ Variabel } & \multirow{2}{*}{ B } & \multirow{2}{*}{ Sig } & \multirow{2}{*}{$\operatorname{Exp}(B)$} & \multicolumn{2}{|c|}{$95 \% \mathrm{Cl}$} \\
\hline & & & & Lower & Upper \\
\hline Exclusive Breastfeeding & 0,138 & 0,867 & 1,148 & 0,229 & 5,747 \\
\hline Family Income & 1,928 & 0,038 & 6,874 & 1,111 & 42,545 \\
\hline Knowledge & 4,725 & 0,0001 & 112,687 & 16,419 & 773,375 \\
\hline Constant & $-4,660$ & 0,001 & 0,009 & & \\
\hline
\end{tabular}

\subsection{Discussion}

\subsubsection{The Effect of Knowledge on the Occurrence of Malnutrition in Infants Age 0-6 Months}

The results of the research in the field showed that there were more respondents in the case group with poor knowledge. The case group mostly gave complementary foods to breast milk to their babies who were under 6 months old, respondents said that their babies often cried, didn't sleep well because they weren't full because they only drank breast milk. complementary foods, they think that their babies are often dissatisfied after they finish feeding, so the mothers decide to give the babies a variety of foods, the consequences of which are unknown to the mother.

Knowledge is not a direct factor that affects the nutritional status of children, but knowledge of nutrition has an important role, because by having sufficient knowledge, especially in the health sector, one can find out various kinds of health problems that may arise so that solutions can be sought [10].

Knowledge of the preparation of menus to meet the needs of infant food intake is very important, because it will have an impact on the nutritional status of children. Selection of the type of food ingredients in such a way as to get the best menu while at the same time trying to vary the menu so that children do not 
feel bored, thus affecting the level of consumption. The level of food consumption will have an impact on the nutritional status of children [2]-[3]. According to the researcher's analysis, it can be concluded that the respondent's knowledge has a relationship between the mother's level of knowledge about nutrition and the nutritional status of infants aged 0-6 months at the Sayurmatinggi Health Center.

The results of this study are in line with Sarbini Dwi's research on knowing the relationship between mother's level of knowledge regarding complementary feeding and nutritional status in children aged 6-24 months. Methods: This study is a cross-sectional study conducted in October 2015-August 2016. The research subjects were mothers of toddlers and toddlers aged 6-24 months with a total of 101 people taken by multistage sampling. The research instrument was a questionnaire on knowledge of complementary feeding, while the research instrument was a dacin with an accuracy of $0.1 \mathrm{~kg}$. Data analysis using Pearson Product Moment correlation. Results: Mother's level of knowledge regarding the provision of complementary feeding with good knowledge is $24.8 \%$, sufficient knowledge is $50.5 \%$ and knowledge is less $24.8 \%$. The nutritional status of under-fives $(\mathrm{BB} / \mathrm{U})$ is good with the most subjects at $93.1 \%$, under-five malnutrition at $1 \%$, and under-nutrition 5.9\% and over nutrition at $0 \%$. MP-ASI with nutritional status of toddlers aged 6-24 months in Semanggi Village, Pasar Kliwon District, Surakarta City (p value =0.014). [11]

Reducing the incidence of malnutrition in infants aged 0-6 months at the Sayurmatinggi Health Center, South Tapanuli Regency, cannot be separated from the role of health workers in providing input for health planning programs that can improve the nutritional status of infants and for health workers, especially nutritionists, can increase nutritional knowledge. the community through counseling during PKK activities, Posyandu and the community must participate in participating in programs that have been proclaimed by the local government so that existing programs run as expected.

\subsubsection{The Effect of Family Income on Malnutrition in Infants Age 0-6 Months}

The results of research in the field, income data obtained from family income per month compared to the BPS standard then categorized into high and low income. The income of research respondents is mostly in the low category ( $\mathrm{Rp} \mathrm{450,000-Rp} \mathrm{850,000} \mathrm{per} \mathrm{month),} \mathrm{from} 45$ respondents there are $55.3 \%$ respondents with income between $\mathrm{Rp} 450,000-\mathrm{Rp} 850,000$ in the low category, the remaining $27.7 \%$ respondents with > than $\mathrm{Rp} 850,000$ in the high category.

Based on the results of research on the relationship between family income and the incidence of malnutrition in infants aged 0-6 months, it was found that 28 people $(31.1 \%)$ had low family incomes where 25 people $(55.6 \%)$ were in the malnutrition group (cases). and only 3 people $(6.7 \%)$ were not malnourished (control). A total of 62 people $(68.9 \%)$ had a high family income of which 20 people $(44.4 \%)$ were in the malnutrition group (cases) and 42 people (93.3\%) were in the non-malnourished group (control). The results of the chi-square statistical test on the family income variable obtained $\mathrm{p}$ value $=0.001(<0.05)$ which means that there is a relationship between family income and the incidence of malnutrition with an OR of 17.500 $(95 \% \mathrm{CI}=4.719-64,897)$, indicating that respondents with income low family 17 times tend to suffer from malnutrition

Family income in order to improve the nutritional status of infants is an important factor. Sugiyono that families who are classified as capable at certain times often experience food shortages. This concerns the opportunity to earn a living from a group of families, perhaps from farming and their own crops, from neighbors, relatives, or purchased from a shop, shop or market. The low income is due to unemployment or difficulty in getting the desired permanent job, 1-2 but it is also influenced by the number of families. The above shows that family income is closely related to sufferers of malnutrition, the higher the family income so that the baby's nutrition is sufficient to meet all the needs of the baby and mother [20]

\subsubsection{The Effect of Exclusive Breastfeeding on the Incidence of Malnutrition in Infants Age 0-6 Months}

Exclusive breastfeeding is breastfeeding only from the time the baby is born until the age of 6 months. During that time the baby is not expected to eat additional liquids such as formula milk, orange juice, tea water, honey, water. In exclusive breastfeeding, babies are also not given additional food such as bananas, biscuits, rice porridge, team rice and so on. Exclusive breastfeeding is expected to be given for up to 6 months. Breastfeeding properly will meet the needs of babies up to the age of 6 months, without complementary foods. Above the age of 6 months, babies need additional food but breastfeeding can be continued until he is 2 years old [18].

Colostrum contains 10-17 times more immune substances than mature milk. Immune substances found in breast milk, among others, will protect babies from diarrheal disease. In a study in South Brazil, infants who were not breastfed had a 14.2 times more chance of dying from diarrhea than exclusively breastfed. Breast milk also reduces the chances of babies getting ear infections, coughs, colds, and allergic diseases [17]-[18] Exclusively breastfed babies are healthier and less sick than babies who are not exclusively breastfed. Healthy children are certainly more intelligent than children who are often sick, especially when the illness is severe [18]. 
The largest proportion in the malnutrition group were children under five who were not breastfed by mothers of children under five as many as 23 children (57.5\%). In the good nutrition group, the largest proportion were infants who were breast-fed by mothers of under-fives as many as 35 children (87.5\%). After being tested with Pearson chi square, $\mathrm{p}=0.000$, which means that there is a significant relationship between breastfeeding and the incidence of malnutrition. Also obtained CI 95\% = 3.067-29.242 which means that breast milk is a risk factor for malnutrition [24].

\section{CONCLUSION}

Based on the research on the Analysis of Factors Affecting Malnutrition (knowledge, family income and exclusive breastfeeding) in infants aged 0-6 months at the Sayur Matinggi Tapanuli Selatan Health Center in 2021, which has been carried out, it can be concluded that the variables related to the incidence of malnutrition in Sayurmatinggi Health Center as follows variables that affect the incidence The most dominant variable that has the greatest influence on the incidence of malnutrition is knowledge having the greatest Exp (B) value of 112.687 with a regression coefficient (B) of 4.725, meaning that respondents who have poor knowledge have 112.687 times the opportunity to suffer from poor nutrition compared to respondents who have good knowledge.

\section{ACKNOWLEDGEMENTS}

Author thanks Elvi Suryani, Nur Aliyah Rangkuti, Novita Sari Batubara, Rya Anastasya Siregar, Ratna Dewi Siregar. In most cases, sponsor and financial support.

\section{REFERENCES}

[1] Almatsier, Basic Principles of Nutrition Science, Vol. 2, $2^{\text {nd }}$ ed, PT Gramedia Pustaka Utama, Jakarta, Indonesia, 2004.

[2] Arisman, Nutrition in the Life Cycle : Textbook of Nutrition Science. Vol. 1, $3^{\text {rd }}$ ed, EGC Medicine Book, Jakarta, Indonesia, 2003.

[3] Arisman, Nutrition in the Life Cycle: Textbook of Nutrition Science. Vol. 2, $2^{\text {nd }}$ ed, EGC Medicine Book, Jakarta, Indonesia, 2008.

[4] Bakri, Fajar, Supariasa, Nutritional Status Assessment. Vol. 1, $1^{\text {st }}$ ed, Buku Kedokteran EGC, Jakarta, 2001

[5] Machfoedz, Research Methodology in Health, Nursing, Midwifery, Medicine, Vol. 3, $2^{\text {nd }}$ ed, Fitramaya, Yogyakarta, Indonesia, 2009

[6] Marmi, Nutrition in Reproductive Health, Vol. 2, $3^{\text {rd }}$ ed, Pustaka Pelajar, Yogyakarta, Indonesia, 2013.

[7] Maryunani, Child Health Sciences in Midwifery. Vol. 3, $3^{\text {rd }}$ ed, CV Trans Info Media. Jakarta:, Indonesia, 2010

[8] Notoatmodjo, Education and Health Behavior. Vol. 1, $1^{\text {st }}$ ed, Rineka Cipta. Jakarta, Indonesia, 2003.

[9] Notoatmodjo, Health Promotion Theory And Application. Vol. 2, $2^{\text {nd }}$ ed, Rineka Cipta, Jakarta, Indonesia, 2005

[10] Notoatmodjo, Health Research Methodology. Vol. 2, $1^{\text {st }}$ ed, Rineka Cipta. Jakarta, Indonesia, 2005.

[11] Sulistyoningsih, Nutrition for Maternal and Child Health. Vol. 1, $1^{\text {st }}$ ed, Graha Ilmu. Yogyakarta, Indonesia, 2011.

[12] Ministry of Health of the Republic of Indonesia. "Basic health research (RISKESDAS)". [2013] November 28, 2021. http:// www.riset.kesdas.go.id.

[13] Ministry of Health Republic of Indonesia. "Indonesian health profile" [2012], November 28, 2021, http://www.pusdiknakes.go.id.

[14] Ministry of Health Republic of Indonesia. "Indonesian health profile", [2013] November 28, 2021, http://www.pusdiknakes.go.id

[15] Ministry of Health Republic of Indonesia. "North Sumatra health profile", [2012] November 28, 2021, http:/www.pusdiknakes.go.id.

[16] World Health Organisation."The statistical highlights in global public health". [2021]. November 28, 2021, http://www.statistic.higlight.in.global.publichealth.html.com.

[17] Eka Prasetia Hati Baculu, M.Juffrie, Siti Helmyati, "Risk Factors for Malnutrition in Toddlers" Donggala Regency, Central Sulawesi Province, Vol. 1 No. 1 [2020], pp 156-160. http://www.digilib.ac.id/buku/penelitian

[18] Mazarina Devi, "Analysis of Factors Influencing the Nutritional Status of Toddlers in Rural Areas" Vol. 1 No. 1, [2021] pp 230-238. http://www. digilib.ac.id/buku/penelitian.

[19] South Tapanuli Health Office . "South Tapanuli Health Office Profile" [2021], October 28, 2021, http://www.pusdiknakes.go.id/.

[20] Sugiyono. Health research methodology. Vol. 1, $2^{\text {nd }}$ ed, Rineka Cipta, Jakarta, Indonesia, 2008.

[21] Sudigdo S. Fundamentals of clinical research methodology. Vol.1, $1^{\text {st }}$ ed, Sagung Seto, Jakarta:, Indonesia, 2011.

[22] Arikunto, Research methodology. Vol.1, $1^{\text {st }}$ ed, Rineka Cipta, Jakarta, Indonesia, 2010.

[23] John W. Research design: Qualitative, quantitative and mixed approaches. Vol.1, $1^{\text {st }}$ ed, Pustaka Pelajar, Yogyakarta, Indonesia, 2012.

[24] Notoatmodjo, S. Health behavioral science. Vol. 2, $2^{\text {nd }}$ ed, Rineka Cipta, Jakarta, Indonesia, 2010.

[25] Darmais Padangsidimpuan Midwifery Academy. Research writing guide. Vol. 1, $1^{\text {st }}$ ed, AKBID Darmais Press, Padangsidimpuan, Indonesia, 2021 